\title{
Enrichment and Identification of Askarel oil (PCB blend) degrading bacteria enriched from landfill sites in Edo State, Nigeria.
}

\author{
*Nwinyi, Obinna C \\ Department of Biological Sciences, College of Science and Technology, \\ Covenant University. KM 10 Idioroko Road, Canaan land, \\ PMB 1023 Ota, Ogun State, Nigeria.
}

\begin{abstract}
Microbial degradation following aerobic biodegradation is one of the means used by microorganisms for the removal of persistent organic pollutants from the soil. Bacterial species namely: Pseudomonas, Micrococcus Arthrobacter and Acinetobacter capable of utilizing askarel oil (PCBs blend) were isolated from landfill soil samples from Uzogholo, Mgboaku and Auchi in Edo State of Nigeria. The isolation of these bacterial species followed an enrichment in minimal salt media were Askarel oil served as the sole carbon source. These bacterial isolates were characterized based on their cultural, morphological, biochemical characteristics and comparison with standard reference organisms. The potentials of these bacterial species to utilize askarel oil were assessed by measuring changes in the turbidity and $\mathrm{pH}$ of the enrichment medium containing varying concentrations of the Askarel oil. From the weekly results obtained, significant increases in the mean turbidity ranged between (0.065- 0.371) and decreases in mean $\mathrm{pH}$ ranged between (6.15- 3.55) for the 21 days incubation period. Some of the bacterial organisms exhibited remarkable utilization of askarel oil at different concentrations in $15 \mu \mathrm{L}$ and $20 \mu \mathrm{L}$ of the askarel minimal salt medium. From these findings, the bacterial species of remarkable potential can be isolated, re-engineered via biotechnology or bioaugmentation for effective remediation of landfill sites polluted with Polychlorinated biphenyls compounds and its derivatives in Nigeria.
\end{abstract}

Keywords: Aerobic biodegradation, bacterial species, biotechnological tools, Edo State, Enrichment, Minimal salt medium.

\section{INTRODUCTION:}

Environmental pollutants of anthropogenic origin are serious concern when introduced into environment at concentrations that impair the biological functioning of the ecosystem or pose risks to plants, animal and human welfare (Scullion, 2006). Polychlorinated biphenyls (PCBs) and its derivatives are among the organic pollutant that have long continued to be a source of concern due to its high persistence, carcinogenic, mutagenic and tetraogenic potential. Polychlorinated biphenyls are organic compounds with several chlorine atoms attached to the biphenyl. Commercial products of Polychlorinated biphenyls can be prepared industrially following catalytic chlorination of biphenyl with anhydrous chlorine in the presence of iron fillings or ferric chloride as a catalyst. Theoretically, about 209 possible polychlorinated biphenyls isomers, differing from each other by the level of chlorination and substitution position exists. In general, the most common isomers are those with an equal number of chlorine atoms on both rings or differ in only one chlorine atom between the rings (Langer, 2005). As a result of potential accumulation and toxic effects within the environment, the manufacture of PCBs were banned in most countries. However due to their non-flammability, chemical stability, high boiling point and electrical insulating properties, PCBs still have applications in electrical equipment such as heat transfer, and hydraulic equipment; as plasticizers in paints, plastics and rubber products; in pigments, dyes and carbonless copy paper. In transformers, they serve as coolants and insulating fluids, in capacitors especially components of early fluorescent light fittings, locomotive's electrical transformers, stabilizing additives in flexible PVC coatings of electrical wiring and electronic components, pesticide extenders, cutting oils, reactive flame retardants, lubricating oils, hydraulic fluids, sealants for caulking in schools and commercial building (Rudel et al.,2008). According to reports of Faroon et al., (2003) more than 1.5 million tons of PCBs were manufactured worldwide between 1927 and the early 1980 s of which a significant amount has been released to the environment. Due to their hydrophobic nature, PCBs tend to be adsorbed strongly to organic matter, thus leading to their 
accumulation in soils and in the food chain (Sawhney et al., 1987). In organic solvents, such as lipids PCBs tend to be soluble. This influences their transport and persistence in the environment. PCBs solubility in water is very low and decreases with increasing degree of chlorination. The solubility of the compound plays an essential role in its degradation. Compounds with high aqueous solubility can be easily degraded by microorganisms than those with low solubility (Imamoglu et al, 2002). Over the years, $\mathrm{PCBs}$ residues may have entered the environment (atmospheric, aquatic and terrestrial) through inadequate elimination by incineration of PCB items. In the atmosphere, owing to the dynamic fluxes of wind speed, there exists a relatively low percentage of PCBs. Furthermore, this process is one of the most common means of PCB transportation and global dispersion in the environment. (Klecka et al, 2000; Mandalakis et al., 2002). Because PCBs can undergo long range of atmospheric transport ie moving from source regions to more remote locations; PCBs can be detected in the biota from different regions of the world, where they have been neither used nor produced. (Wania, 2003; Braune et al., 2005). According to Offenberg et al., (2005) the emission of PCBs into the coastal atmosphere from industrial areas may lead to increased depositional fluxes. In the reports of Gevao et al., (2006) equipment dumps, landfills, sewage sludge and PCBcoated silos represent large PCB reservoirs which frequently find their away to contaminate the terrestrial area and groundwater. PCBs have been found to cause a variety of adverse health effects in animals which range from immune, reproductive, nervous and endocrine disorders. In human there exist supportive evidence for potential carcinogenic and non-carcinogenic effects of PCBs (USEPA, 1987).Transformation of PCBs and there derivatives is a critical step determining their fate and persistence in the environment. The effectiveness of remediation of contaminated sites depends on degradation rates and the conditions present in the environment. These includes: the degree of biphenyl chlorination; position of chlorine atoms in the biphenyl nucleus; species of microorganisms, their activity and in-between interactions; the structure of a given PCB compound; the presence of substituents and their position in the molecule; the presence of toxic or inhibitory substances; solubility, temperature, $\mathrm{pH}$, light, and concentration of the pollutant (Imamoglu et al., 2002). Biodegradation using microorganisms depends on the array of enzymes produced them; and possible use of the pollutant as source of carbon and energy. Following the isolation of two bacterial strain (Achromobacter species) by Ahmed and Focht in 1973, the overall perspective of PCBs as immutable chemicals were changed. From then onwards, quite a number of bacterial strains capable of utilization of PCBs have been noted. (Furukawa et al., 1979; Bopp 1986; Bedard et al., 1987, Kim and Picardal 2000 and Adebusoye et al., 2008). However these notable achievements, in most developing countries such as Nigeria most PCB items and PCB waste oils are discharged into the environment without proper monitoring and determination of the fate of such compounds (Adebusoye et al., 2008). Furthermore from research studies, the isolation and studies on degradation of PCB item and its derivatives (transformer oil) in Nigeria is still at its infancy. However this, there are few notable scientists in Nigeria that have provided groundbreaking research for continuous search for more bacterial species capable of utilizing PCB and its derivatives as carbon sources. To contribute in the quest for more bacterial species capable of growth and utilization of PCB items /(transformer oilaskarel oil),author seek to isolate, characterize and determine the potentials of bacterial species from landfill sites in Edo State ,Nigeria capable of utilization of askarel oil (a PCB blend) as carbon source.

\section{MATERIALS AND METHODS}

Chemical and Reagents: All chemicals and reagents were of analytical grade. The (PCB blend) Askarel was generously provided by Power Holding Company of Nigeria. All other chemicals and reagents were obtained from Sigma- Aldrich Chemicals Co Ltd England.

Sample Collection: The soil samples were collected from landfill sites containing organic wastes, sewage sludge, old electrical equipment and waste oil in Uzogholo, Mgboaku and Auchi in Edo State, Nigeria. Geographical coordinates are $7^{\circ} 4^{\prime} 0^{\prime \prime}$ North, 6 $16^{\prime} 0^{\prime \prime}$ East. The site had been contaminated with wastes from organic and inorganic pollutants for several years. The soil samples were collected randomly at sites with indications of low to high level wastes. The soil was collected from a depth of about $2-7 \mathrm{~cm}$ deep using a sterile hand trowel. The soil samples were placed in separate sterile jars and transported back at ambient temperatures for further studies. The trowel surface was sterilized with $70 \%$ ethanol prior to collection of each sample. 


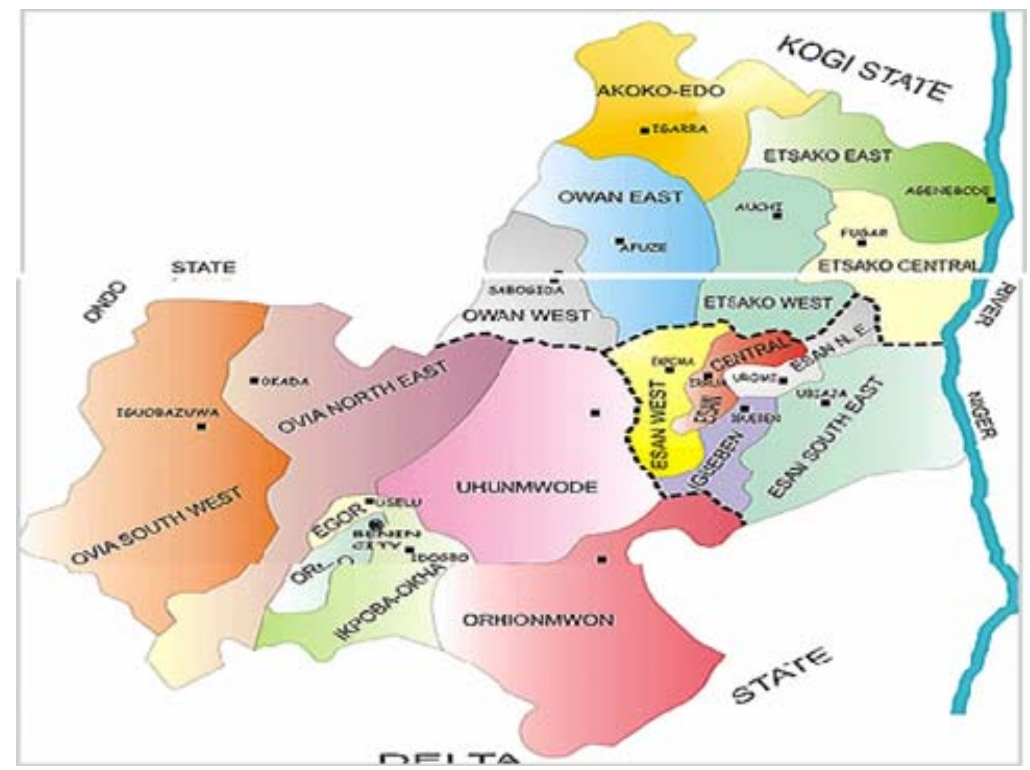

Fig : Map showing the Edo state

Source : Google.com

Isolation and Enrichment of Aerobic Indigenous

Bacterial Strains: The enrichment and degradation potential of askarel oil were conducted in Minimal salt medium containing in $\mathrm{CaCO}_{3}(2 \mathrm{mg} / \mathrm{L}), \mathrm{MgSO}_{4} .7 \mathrm{H}_{2} \mathrm{O}$ (0.1g/L), $\quad \mathrm{ZnSO}_{4} . \quad 7 \mathrm{H}_{2} \mathrm{O}(1.44 \mathrm{mg} / \mathrm{L}), \quad \mathrm{CuSO}_{4}$. $5 \mathrm{H}_{2} \mathrm{O}(0.25 \mathrm{mg}), \quad \mathrm{H}_{3} \mathrm{PO}_{4}(0.06 \mathrm{mg} / \mathrm{L}), \mathrm{HCL}(51.3 \mu \mathrm{L})$ and Askarel oil (PCB blend) about 20ppm as carbon source. The $\mathrm{pH}$ was adjusted to 7.0. Cultures were incubated in $160 \mathrm{~mL}$ serum bottles containing a liquid volume of $30 \mathrm{~mL}$ with mouth plugged with sterile cotton wool and incubated at room temperature $\left(25^{\circ} \mathrm{C}\right)$ for a period of three weeks. Incubation at $37^{\circ} \mathrm{C}$ is lethal to many soil bacteria. For the bacterial isolation from enrichment culture, transfers to fresh Askarel minimal salt medium using about $10 \%$ of inoculums from the previous enrichment was done weekly and incubated at $25^{\circ} \mathrm{C}$. This procedure was repeated for four successive transfers. Pure cultures were isolated from the enrichment media by plating out on nutrient agar sprayed with Askarel. Discrete single colonies were selected and inoculated on Minimal agar medium sprayed with Askarel. The process was repeated severally to obtain pure cultures capable of growth on Askarel oil (Liu et al., 2002, Nwinyi et al., 2008; Nwinyi,2010).

Identification and characterization of the Isolated Bacterial Strains: The pure bacterial strains were identified on the basis of their morphological and biochemical tests. The pure cultures of the bacterial isolates were subjected to various morphological and biochemical characterization tests such as color, shape, elevation, consistency, margin , Catalase test, MRVP (methyl red-voges proskauer test), fermentation of sugars, kovacs citrate, indole, hydrolysis of starch, and sensitivity tests. In order to determine the identity of bacteria isolates, results were compared with standard references of Bergey's Manual of Determinative Bacteriology 2nd edition (Buchanan and Gibbon, 1974; Olutiola et al., 1991).

Determination of Growth Profile in Different Concentration of Askarel Blend: The isolates were inoculated into different concentrations in $5 \mu \mathrm{L}, 10 \mu \mathrm{L}$, $15 \mu \mathrm{L}$ and $20 \mu \mathrm{L}$ askarel oil minimal salt medium. This was done to determine the tolerance level, degradation/ transformation of Askarel oil through the utilization of Askarel oil as carbon source. The cultures were then incubated at room temperature $25^{\circ} \mathrm{C}$ for a period of three weeks. The Growth was monitored by measuring weekly the turbidity at $540 \mathrm{~nm}$ using standardized Hanna $\mathrm{H} 198703$ Turbidimeter and $\mathrm{pH}$ by Hanna microprocessor $\mathrm{pH}$ meter.

\section{RESULTS}

Characterization of the isolates: $A$ total of 5 different microbial colonies were selected upon screening individual isolates for growth on Askarel oil minimal media. The isolates were characterized using the morphological, cultural and biochemical characteristics with results shown in table 1.

Determination of growth in different concentration of Askarel minimal salts: The growth (utilization of askarel) by these isolates in different concentration of Askarel minimal salt medium are summarized in the Table 2. All the strains showed visible signs of growth on different compounds. Interestingly growth with production of blue coloration was seen on $15 \mu \mathrm{L}, 20 \mu \mathrm{L}$ concentrations of Askarel minimal salt containing the Pseudomonas spp. 
Table: 1. Shows the cultural, morphological and biochemical characteristics of the bacterial isolates

\begin{tabular}{|c|c|c|c|c|c|}
\hline & A1 & $\mathrm{A} 2$ & B1 & B2 & C1 \\
\hline & $\overline{\mathrm{Al}}$ & $\mathrm{A} 2$ & B1 & B2 & $\mathrm{C} 1$ \\
\hline Gram's reaction & - & + & + & + & - \\
\hline Shape & Rod & Cocci & Cocci & Rod & Coccobaccilli \\
\hline Motility & Motile & Non motile & Non motile & Non motile & Non motile \\
\hline Spore formation & - & - & - & - & - \\
\hline Acid fast & - & - & - & - & - \\
\hline $\begin{array}{l}\text { Form on Nutrient } \\
\text { agar slant }\end{array}$ & Echinulate & Echinulate & Echinulate & Echinulate & Filiform \\
\hline $\begin{array}{l}\text { Growth on Nutrient } \\
\text { agar slant. }\end{array}$ & Large & Moderate & Moderate & Large & Moderate \\
\hline Optical features & Translucent & Transparent & Transparent & Translucent & Transparent \\
\hline $\begin{array}{l}\text { Growth on Nutrient } \\
\text { Broth }\end{array}$ & $\begin{array}{l}\text { Turbid with } \\
\text { pellicles }\end{array}$ & $\begin{array}{l}\text { Turbid with } \\
\text { pellicles }\end{array}$ & $\begin{array}{l}\text { Turbid with } \\
\text { pellicles }\end{array}$ & $\begin{array}{l}\text { Uniform } \\
\text { turbidity }\end{array}$ & $\begin{array}{l}\text { Turbid with } \\
\text { pellicles }\end{array}$ \\
\hline
\end{tabular}

\begin{tabular}{|c|c|c|c|c|c|}
\hline Catalase & + & + & + & + & + \\
\hline Urease & - & + & + & + & + \\
\hline Starch hydrolysis & - & - & - & + & + \\
\hline Growth in 5\% NaCL & + & + & + & + & + \\
\hline Growth in $\mathrm{pH} 6.0$ & + & + & + & + & + \\
\hline Growth at $35^{\circ} \mathrm{C}$ & + & + & + & + & + \\
\hline Lactose fermentation & - & - & - & - & - \\
\hline Sucrose fermentation & - & - & - & - & - \\
\hline Maltose fermentation & - & - & - & - & - \\
\hline Glucose fermentation & - & - & - & - & - \\
\hline Indole & - & - & - & + & - \\
\hline Methyl Red & - & - & - & - & - \\
\hline Citrate & + & - & - & + & + \\
\hline Probable Organism & $\begin{array}{l}\text { Pseudomonas } \\
\text { spp }\end{array}$ & Micrococcus spp & $\begin{array}{l}\text { Micrococcus } \\
\text { spp }\end{array}$ & $\begin{array}{l}\text { Arthrobacter } \\
\text { spp }\end{array}$ & $\begin{array}{l}\text { Acinetobacter } \\
\text { spp }\end{array}$ \\
\hline
\end{tabular}

Key: + = Growth, - = No growth A=Isolates from Uzogholo, B=Isolates from Mgboaku, C=Isolates from Auchi 
Table 2.0 Shows the different $\mathrm{pH}$ and Optical density readings at $(540 \mathrm{~nm})$ recorded for the 21 days incubation period at different concentrations $(5 \mu \mathrm{L}, 10 \mu \mathrm{L} 15 \mu \mathrm{L}, 20 \mu \mathrm{L})$

\begin{tabular}{|l|l|l|l|l|}
\hline MICROORGANISM & $\mathrm{pH}$ at $5 \mu \mathrm{L}$ after 1week & $\mathrm{pH}$ at $5 \mu \mathrm{Lafter} 2$ weeks & $\mathrm{pH}$ at $5 \mu \mathrm{L}$ after $3 w e e k s$ & Mean $\mathrm{pH}$ at $5 \mu \mathrm{L}$ \\
\hline Pseudomonas spp & 5.57 & 5.92 & 5.85 & 5.78 \\
\hline Micrococcus spp & 5.60 & 5.91 & 5.97 & 5.83 \\
\hline Micrococcus spp & 5.59 & 5.96 & 5.98 & 5.84 \\
\hline Arthrobacter spp & 5.89 & 6.22 & 6.23 & 6.11 \\
\hline Acinetobacter spp & 5.90 & 6.30 & 6.27 & 6.15 \\
\hline
\end{tabular}

\begin{tabular}{|l|l|l|l|l|}
\hline MICROORGANISM & $\mathrm{pH}$ at $10 \mu \mathrm{L}$ after 1week & $\begin{array}{l}\mathrm{pH} \text { at } 10 \mu \mathrm{L} \text { after } \\
2 \text { weeks }\end{array}$ & $\begin{array}{l}\mathrm{pH} \text { at } 10 \mu \mathrm{L} \text { after } \\
\text { 3weeks }\end{array}$ & Mean $\mathrm{pH}$ at $10 \mu \mathrm{L}$ \\
\hline Pseudomonas spp & 5.49 & 5.99 & 6.05 & 5.81 \\
\hline Micrococcus spp & 5.57 & 5.91 & 5.95 & 5.80 \\
\hline Micrococcus spp & 5.68 & 6.07 & 6.13 & 5.96 \\
\hline Arthrobacter spp & 5.89 & 6.22 & 6.23 & 6.11 \\
\hline Acinetobacter spp & 5.90 & 6.30 & 6.27 & 6.15 \\
\hline
\end{tabular}

\begin{tabular}{|l|l|l|l|l|}
\hline MICROORGANISM & $\mathrm{pH}$ at $15 \mu \mathrm{L}$ after 1week & $\begin{array}{l}\mathrm{pH} \text { at } 15 \mu \mathrm{L} \text { after } \\
2 \text { weeks }\end{array}$ & $\begin{array}{l}\mathrm{pH} \text { at } 15 \mu \mathrm{L} \text { after } \\
\text { 3weeks }\end{array}$ & Mean $\mathrm{pH}$ at $15 \mu \mathrm{L}$ \\
\hline Pseudomonas spp & 3.89 & 3.46 & 3.30 & 3.55 \\
\hline Micrococcus spp & 3.66 & 4.18 & 4.65 & 4.16 \\
\hline Micrococcus spp & 4.54 & 5.20 & 5.50 & 5.08 \\
\hline Arthrobacter spp & 4.63 & 5.16 & 5.40 & 5.06 \\
\hline Acinetobacter spp & 4.92 & 5.53 & 5.78 & 5.41 \\
\hline
\end{tabular}

\begin{tabular}{|l|l|l|l|l|}
\hline MICROORGANISM & $\mathrm{pH}$ at $20 \mu \mathrm{L}$ after 1week & $\begin{array}{l}\mathrm{pH} \text { at } 20 \mu \mathrm{L} \text { after } \\
2 \text { weeks }\end{array}$ & $\begin{array}{l}\mathrm{pH} \text { at } 20 \mu \mathrm{L} \text { after } 3 \\
\text { weeks }\end{array}$ & Mean $\mathrm{pH}$ at 20 $\mu \mathrm{L}$ \\
\hline Pseudomonas spp & 3.59 & 3.62 & 3.83 & 3.68 \\
\hline Micrococcus spp & 5.59 & 5.78 & 5.90 & 5.76 \\
\hline Micrococcus spp & 5.55 & 5.42 & 5.62 & 5.53 \\
\hline Arthrobacter spp & 4.18 & 4.30 & 4.62 & 4.37 \\
\hline Acinetobacter spp & 4.84 & 5.47 & 5.69 & 5.33 \\
\hline
\end{tabular}

\begin{tabular}{|c|c|c|c|c|}
\hline MICROORGANISM & $\begin{array}{l}\text { Optical density at } 5 \mu \mathrm{L} \\
\text { after } 1 \text { week }\end{array}$ & $\begin{array}{l}\text { Optical density at } 5 \mu \mathrm{L} \\
\text { after } 2 \text { weeks }\end{array}$ & $\begin{array}{l}\text { Optical density at } \\
5 \mu \text { Lafter 3weeks }\end{array}$ & $\begin{array}{l}\text { Mean Optical density at } \\
5 \mu \mathrm{L}\end{array}$ \\
\hline Pseudomonas spp & 0.053 & 0.069 & 0.110 & 0.077 \\
\hline Micrococcus spp & 0.051 & 0.068 & 0.087 & 0.069 \\
\hline Micrococcus spp & 0.038 & 0.068 & 0.095 & 0.067 \\
\hline Arthrobacter spp & 0.046 & 0.069 & 0.121 & 0.079 \\
\hline Acinetobacter spp & 0.063 & 0.091 & 0.114 & 0.089 \\
\hline
\end{tabular}

\begin{tabular}{|l|l|l|l|l|}
\hline MICROORGANISM & $\begin{array}{l}\text { Optical density at } 10 \mu \mathrm{L} \\
\text { after 1week }\end{array}$ & $\begin{array}{l}\text { Optical density at } 10 \mu \mathrm{L} \\
\text { after 2weeks }\end{array}$ & $\begin{array}{l}\text { Optical density at } 10 \mu \mathrm{L} \\
\text { after 3weeks }\end{array}$ & $\begin{array}{l}\text { Mean Optical density at } \\
10 \mu \mathrm{L}\end{array}$ \\
\hline Pseudomonas spp & 0.073 & 0.100 & 0.144 & 0.106 \\
\hline Micrococcus spp & 0.043 & 0.085 & 0.124 & 0.084 \\
\hline Micrococcus spp & 0.066 & 0.083 & 0.091 & 0.080 \\
\hline Arthrobacter spp & 0.063 & 0.061 & 0.072 & 0.065 \\
\hline Acinetobacter spp & 0.060 & 0.060 & 0.077 & 0.066 \\
\hline
\end{tabular}

\begin{tabular}{|c|c|c|c|c|}
\hline MICROORGANISM & $\begin{array}{l}\text { Optical density at } 15 \mu \mathrm{L} \\
\text { after } 1 \text { week }\end{array}$ & $\begin{array}{l}\text { Optical density at } 15 \mu \mathrm{L} \\
\text { after } 2 \text { weeks }\end{array}$ & $\begin{array}{l}\text { Optical density at } 15 \mu \mathrm{L} \\
\text { after } 3 \text { weeks }\end{array}$ & $\begin{array}{l}\text { Mean Optical density at } \\
15 \mu \mathrm{L}\end{array}$ \\
\hline Pseudomonas spp & 0.139 & 0.327 & 0.350 & 0.272 \\
\hline Micrococcus spp & 0.329 & 0.316 & 0.359 & 0.334 \\
\hline Micrococcus spp & 0.244 & 0.216 & 0.232 & 0.231 \\
\hline Arthrobacter spp & 0.196 & 0.203 & 0.220 & 0.206 \\
\hline Acinetobacter spp & 0.175 & 0.166 & 0.182 & 0.174 \\
\hline
\end{tabular}

\begin{tabular}{|l|l|l|l|l|}
\hline MICROORGANISM & $\begin{array}{l}\text { Optical density at 20 } \mu \mathrm{L} \\
\text { after 1week }\end{array}$ & $\begin{array}{l}\text { Optical density at 20 } \mu \mathrm{L} \\
\text { after 2weeks }\end{array}$ & $\begin{array}{l}\text { Optical density at 20 } \mu \mathrm{L} \\
\text { after 3weeks }\end{array}$ & $\begin{array}{l}\text { Mean Optical density at } \\
20 \mu \mathrm{L}\end{array}$ \\
\hline Pseudomonas spp & 0.305 & 0.396 & 0.412 & 0.371 \\
\hline Micrococcus spp & 0.260 & 0.108 & 0.270 & 0.213 \\
\hline Micrococcus spp & 0.086 & 0.199 & 0.268 & 0.184 \\
\hline Arthrobacter spp & 0.228 & 0.262 & 0.303 & 0.264 \\
\hline Acinetobacter spp & 0.162 & 0.162 & 0.169 & 0.164 \\
\hline
\end{tabular}


Agric. Biol. J. N. Am., 2011, 2(1): 89-100

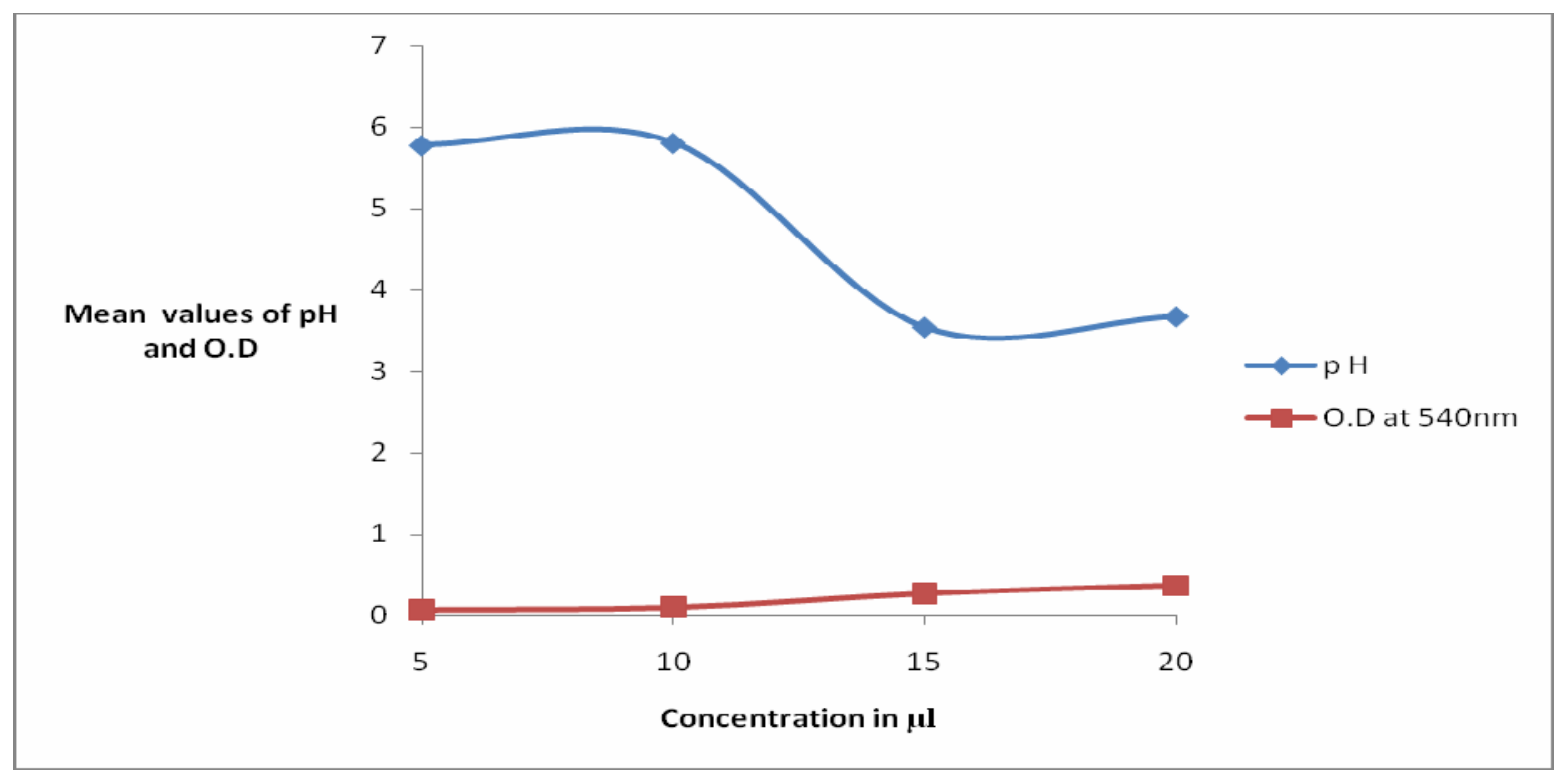

Fig. 1 shows graph for mean values of $\mathrm{pH}$ and optical density against different concentration levels of Askarel oil in minimal medium for $\mathbf{2 1}$ days by Pseudomonas spp isolated from Uzogholo.

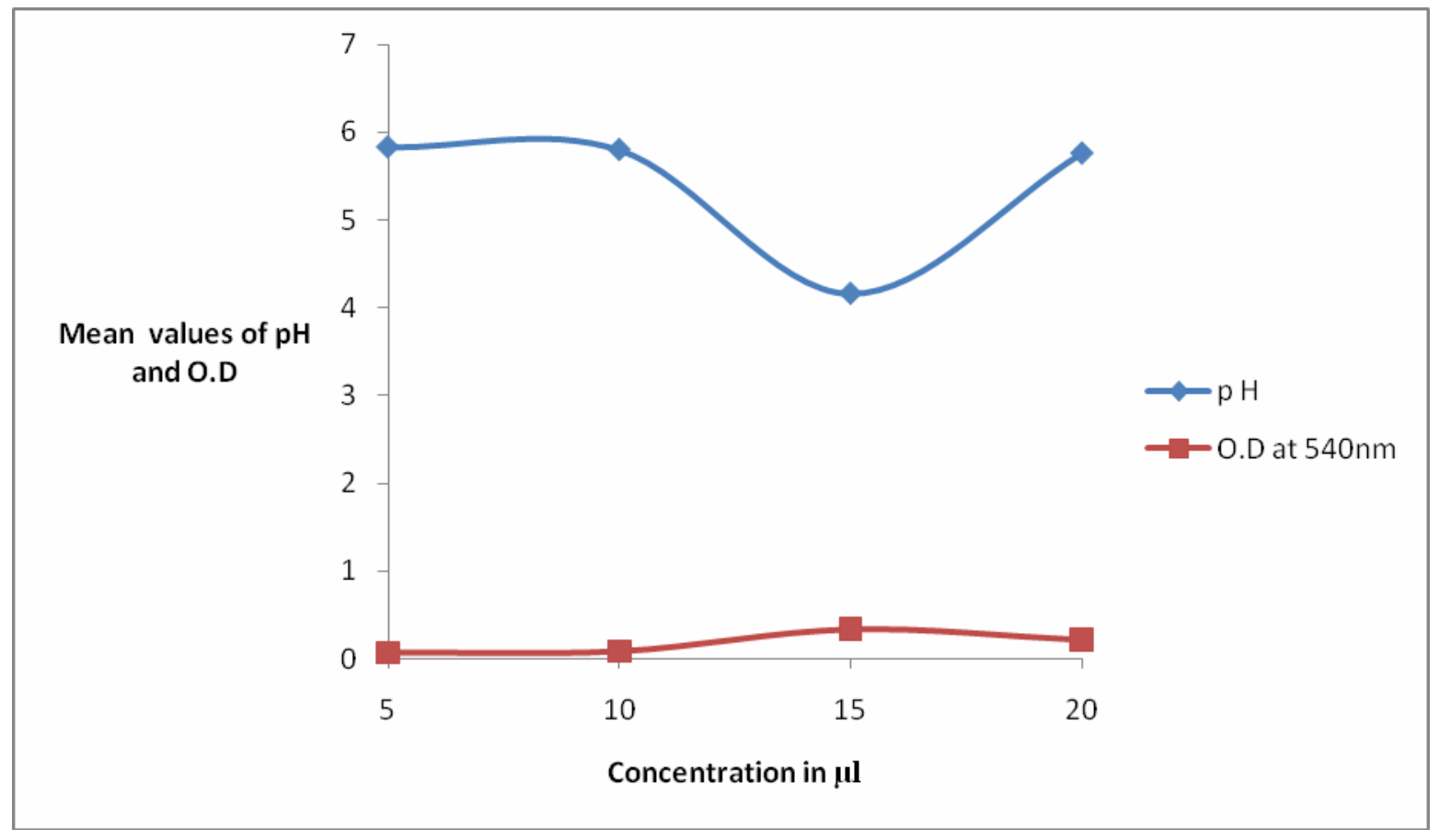

Fig. 2 shows graph for mean values of $\mathrm{pH}$ and optical density against different concentration levels(5uL,10uL,15uL,20uL) of PCB blend in minimal medium for 21 days by Micrococcus spp isolated from Uzogholo. 
Agric. Biol. J. N. Am., 2011, 2(1): 89-100

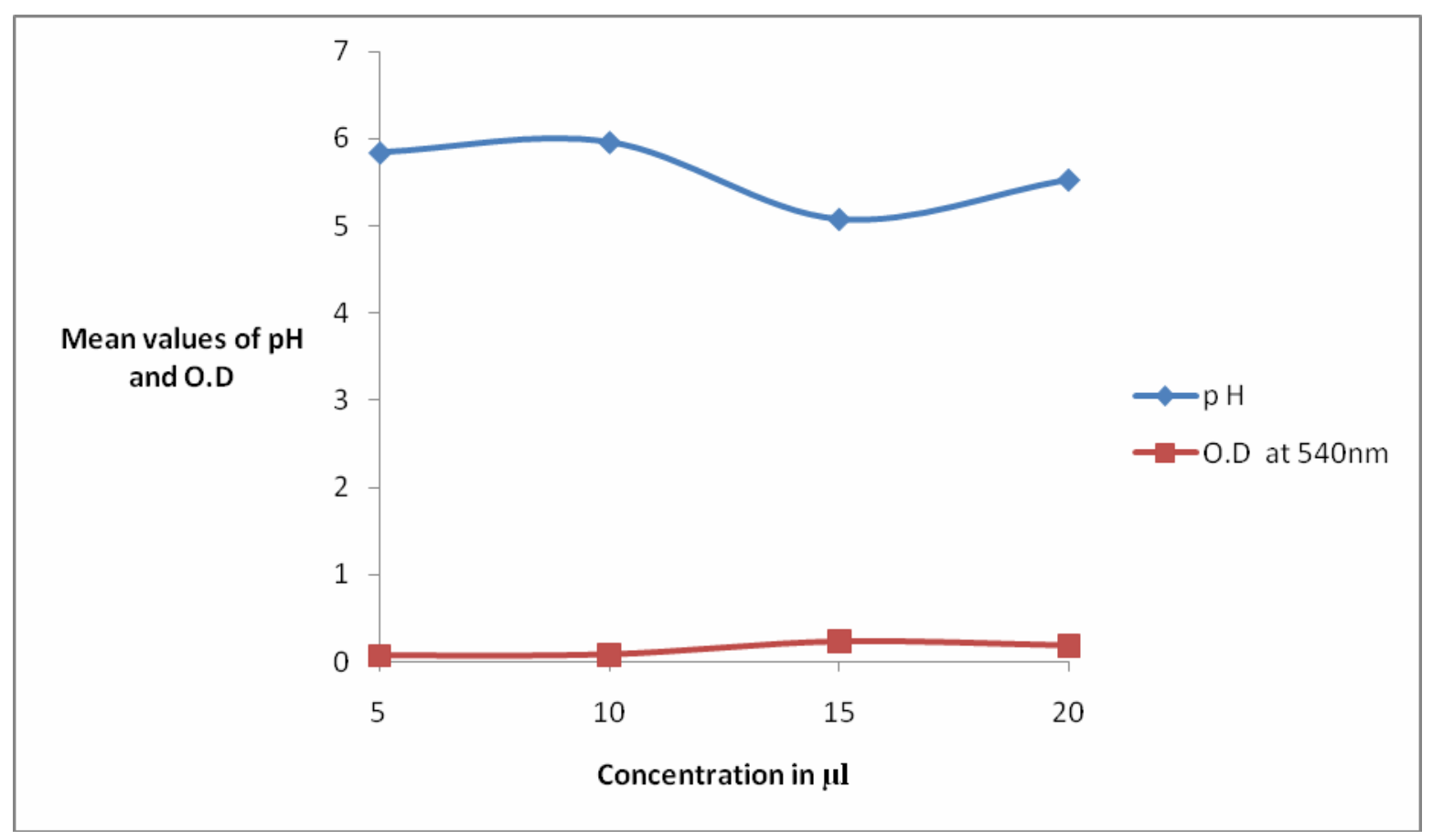

Fig. 3: shows graph for mean values of $\mathrm{pH}$ and optical density against different concentration levels of askarel (PCB blend) in minimal medium for 21 days by Micrococcus spp isolated from Mgboaku.

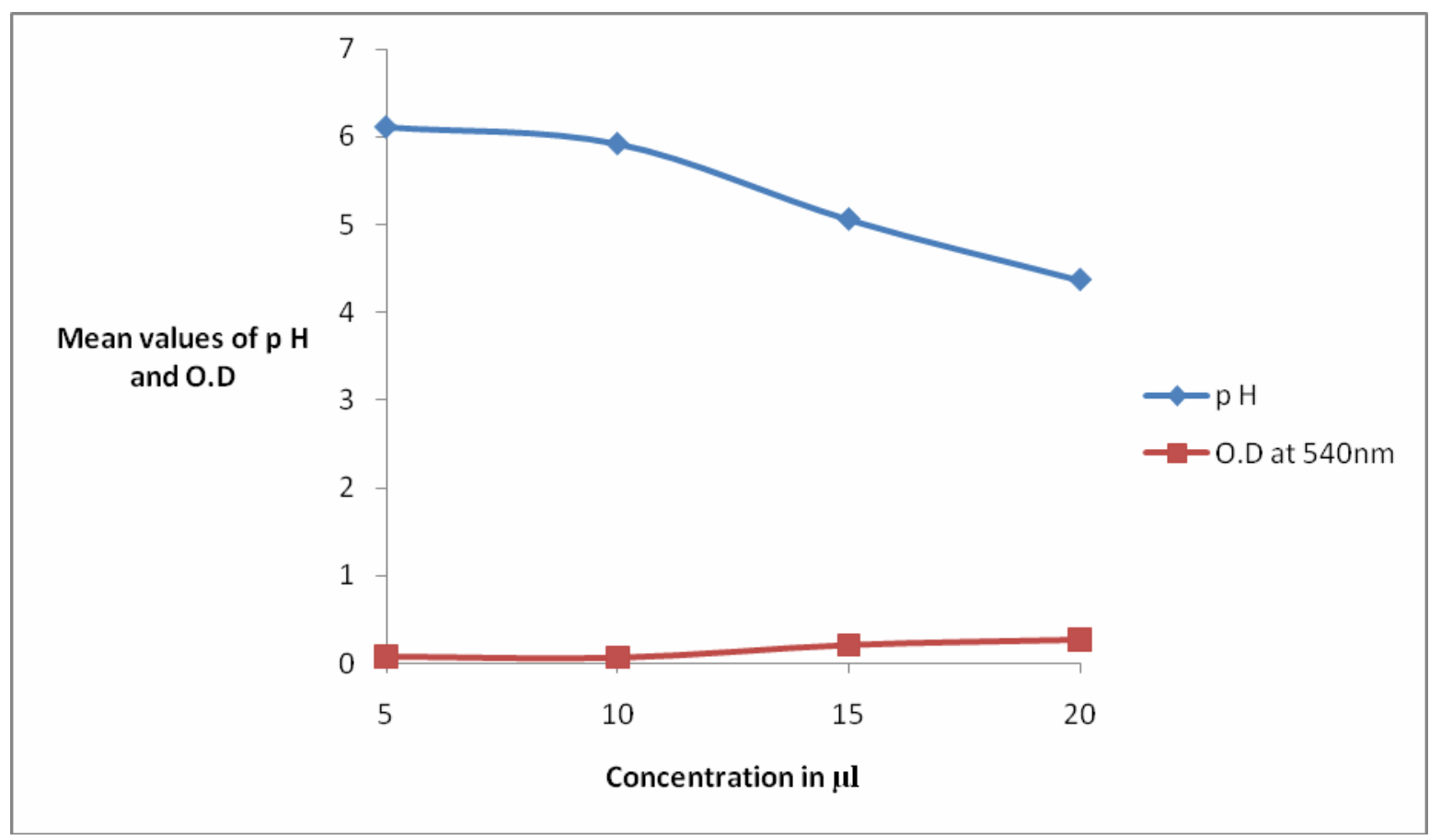

Fig. 4 : Shows graph for mean values of $\mathrm{pH}$ and optical density against different concentration levels of askarel (PCB blend )in minimal medium for 21 days by Arthrobacter spp.isolated from Mgboaku. 
Agric. Biol. J. N. Am., 2011, 2(1): 89-100

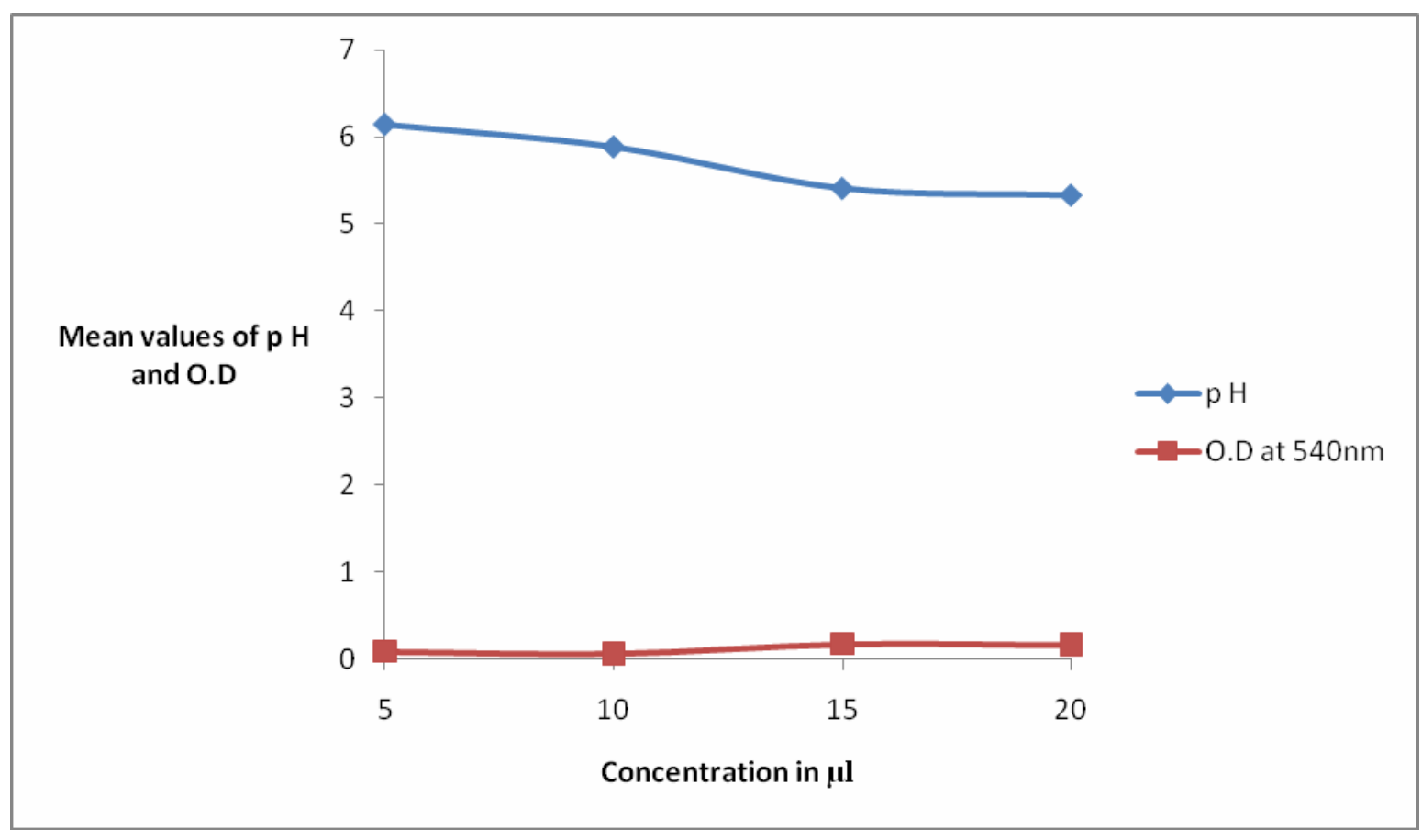

Fig. 5 Shows graph of mean values of $\mathrm{p} \mathrm{H}$ and optical density(Turbidity) against different concentration levels of askarel (PCB blend) in minimal medium for 21 days by Acinetobacter spp isolated from Auchi.

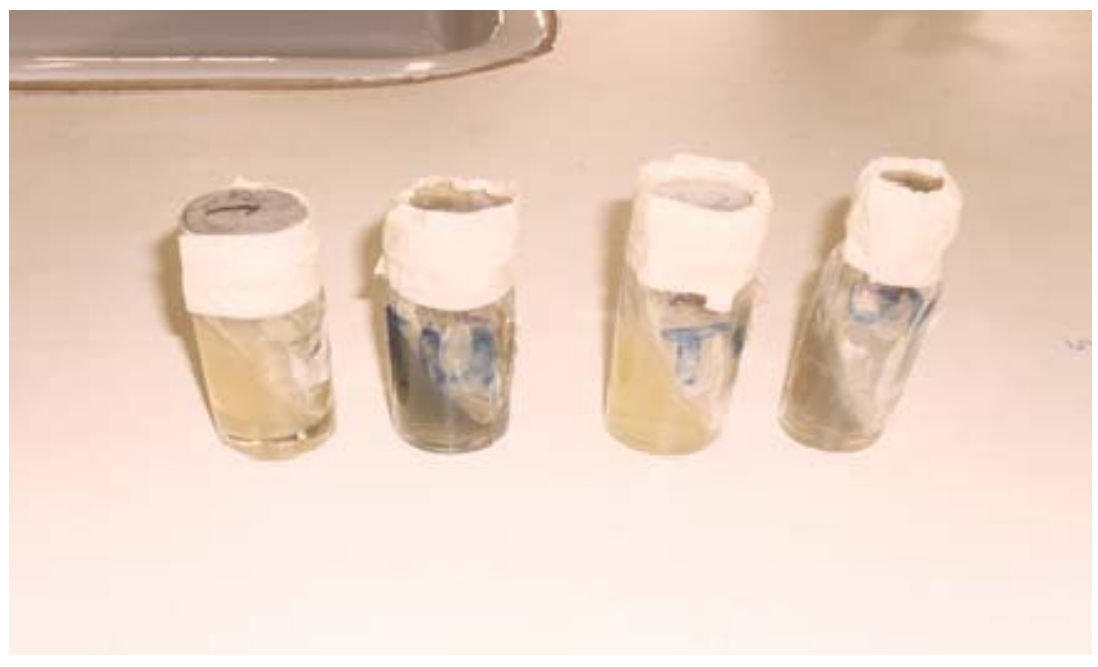

Plate1: shows bacteria isolated from soil samples in Nutrient Agar slant; Micrococcus spp, Pseudomonas spp, Arthrobacter spp, Acinetobacter spp respectively. 
Agric. Biol. J. N. Am., 2011, 2(1): 89-100

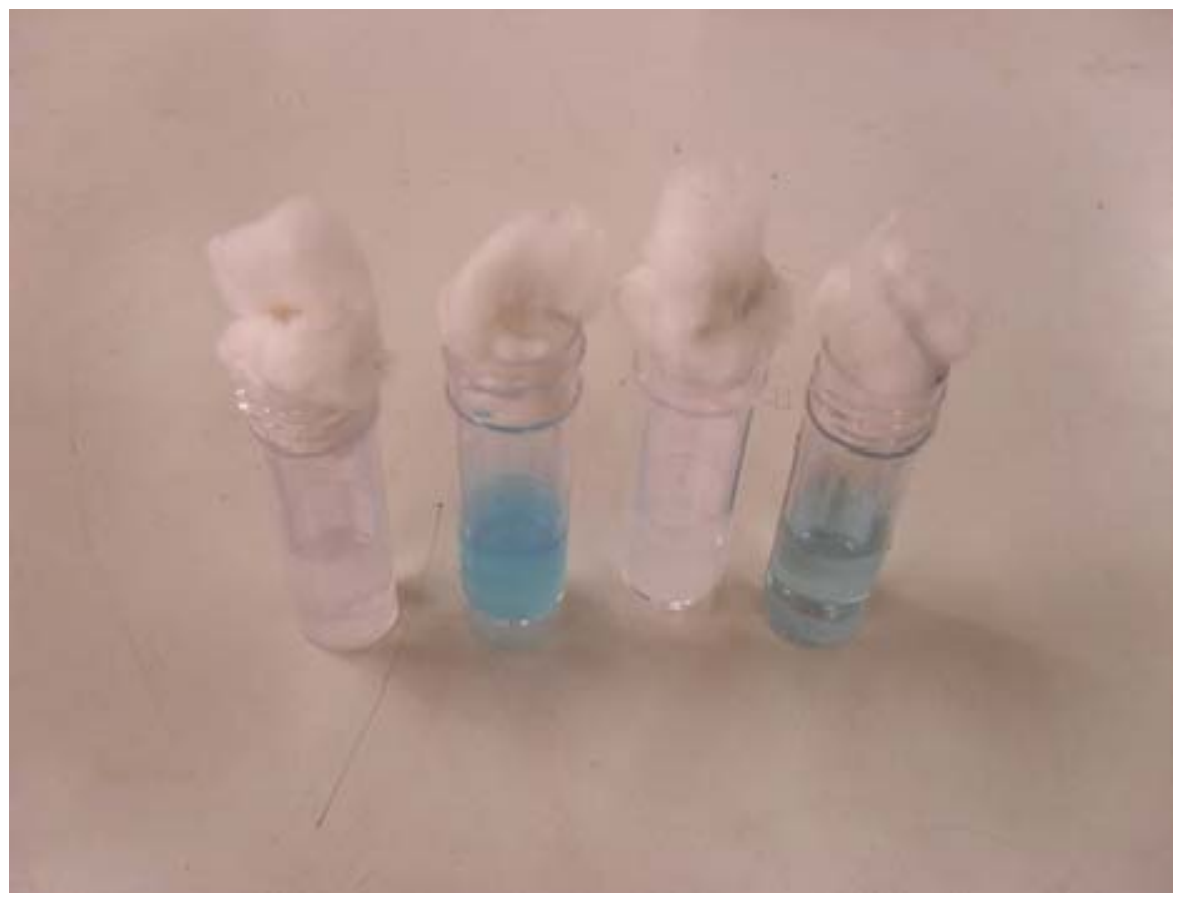

Plate 2: Shows Pseudomonas spp which produces blue coloration at a PCB blend (askarel) concentration of $15 \mu$ Land $20 \mu \mathrm{L}$.

\section{DISCUSSION}

To make the best of isolation of bacterial species with special abilities from sites of pollution, enrichment method is still an all-important process particularly were the target pollutant serve as the carbon and energy sources. In addition, previous exposures of these bacterial species to the target pollutants often trigger acclimatization and assemblage of important mechanisms that enhance the potential of these microorganisms in degrading the pollutants. In this research investigation, Pseudomonas spp, Arthrobacter spp, Micrococcus spp , and Acinetobacter spp were isolated from soils of different landfill sites in Edo State, Nigeria. Pseudomonas spp and Micrococcus spp were isolated from soil samples from Uzogholo; Micrococcus spp and Arthrobacter spp were isolated from soil samples from Mgboaku while Acinetobacter spp was isolated from soil samples from Auchi. Polychlorinated biphenyls (PCBs) are biodegraded in two general ways; aerobic metabolism via co-metabolism and anaerobically by reductive dehalogenation (Sierra et al.,2003). In this research biodegradation was carried out aerobically were askarel oil served as principal growth substrate. These isolated organisms were then grown in different concentrations at $(5 \mu \mathrm{L}, 10 \mu \mathrm{L}$,
$15 \mu \mathrm{L}, 20 \mu \mathrm{L})$ of polychlorinated biphenyls blend (askarel oil) in the minimal salt media. From the observed $\mathrm{pH}$ and optical density (O.D) of the growth profile of each bacterial species, obtained results agrees with previous reports of organic pollutant utilization. From recent findings, growth of microorganisms in organic pollutants is often indicated by an increase in turbidity and decrease in $\mathrm{pH}$ (Nwinyi et al., 2008). In this research growth occurred at different rate among the organisms isolated. Pseudomonas spp utilized the askarel oil significantly at concentrations in $15 \mu \mathrm{L}$ and $20 \mu \mathrm{L}$ of askarel minimal media, Micrococcus species isolated from Uzogholo and Mgboaku utilized PCBs blend (Askarel oil) minimal media remarkably at concentration of $15 \mu \mathrm{L}$. These findings, showed consistency in behavior between the two Micrococcus spp isolated, possibly they could be of the same phylogeny. Acinetobacter spp isolated from land fill sites in Auchi showed minimal utilization of PCBs blend (askarel oil). This inability of Acinetobacter spp to thrive well in the PCBs blend may be as a result of entrapment of Askarel oil within some part of the biological membrane (Sikkema et al., 1995). Rosenberg et al.,(1988) reported that emulsifying and dispersing activities of Acinetobacter species appears to be due to different materials, and 
is restricted to a relatively small number of the species. Furthermore, PCB congener, 2, 2', 5, 5'tetrachlorobiphenyl, has been shown to affect the membrane of Ralstonia eutropha H850 due to its accumulation in the cytoplasmic membrane (Kim et al., 2001). Although neither the mass flow rate of the cytoplasmic membrane nor that between the cytoplasmic membrane and cytosol is known, it seems likely that the entrapment of PCBs within the membrane reduces both the accessibility of PCBs to the degradation enzymes and the efficiency of PCB degradation. In addition, the accumulation of hydrophobic compounds in the cytoplasmic membrane fluidizes and disrupts its function (Sikkema et al., 1995), thus the accumulation of PCBs in the cytoplasmic membrane may also affect cell viability. Most likely the reduced metabolism rate may be due to high $\mathrm{CO}_{2}$ concentrations since there is no rapid transfer of oxygen were in most research, additional aeration is provided to assist the organisms to aerobically breakdown the pollutants. From research studies, high $\mathrm{CO}_{2}$ can inhibit cell growth were the headspace may not have been effectively purged, thus the high $\mathrm{CO}_{2}$ may have caused the decline in growth rate.

Utilization of Askarel oil (PCBs blend) by Arthrobacter spp occurred significantly at $15 \mu \mathrm{l}$ and $20 \mu \mathrm{l}$. Pseudomonas spp showed highest degradation of the askarel oil with $\mathrm{pH}$ of 3.55. This is probably because it is not a Gram positive organism. According to (Prescott et al., 2002), Gram positive bacteria are usually more sensitive than Gram negative bacteria towards lipophilic toxic substrates, possible because they lack protection by the outer membrane. Furthermore, Pseudomonas spp had been noted as one of the major bacterial species that help degrade most organic pollutant. This is because of their ability to possess varieties of catabolic genes that are resident on the plasmids.

From studies, degradation of PCBs, is initiated by an enzyme called biphenyl 2,3-dioxygenase. Biphenyl 2,3-dioxygenases belong to a large family of Rieske non-heme iron oxygenases (Gibson and Parales,2000). They comprise a terminal oxygenase composed of a large $\alpha$ - and a small $\beta$-subunit, a ferredoxin and a ferredoxin reductase. The ferredoxin and ferredoxin reductase act as an electron transport system to transfer electrons from NADH to the terminal oxygenase. The cis-2, 3-dihydro-2,3dihydroxybiphenyl formed by this reaction is dehydrogenated by a dehydrogenase to give 2,3-di hydroxybiphenyl, which is subject to extradiol cleavage. The 2-hydroxy-6-oxo-6-phenylhexa-2,4dienoate thereby formed undergoes hydrolysis, yielding benzoate and 2- hydroxypenta-2,4-dienoate as reaction products. This sequence of reactions forms the biphenyl upper pathway as described by Ahmed and Focht, in 1973. They were the first to describe that biphenyl-degrading organisms of bacterial species have the capacity to transform several PCB congeners. Since then, a major focus of research on biphenyl-degrading organisms is their capability to transform PCBs, which differs significantly between different isolates (Gibson and Parales, 2000). Following incubation for 7 days in askarel oil (PCB blend) minimal salt containing Pseudomonas spp, there was a remarkable change in the medium from colorless to light blue at a concentration of $15 \mu \mathrm{L}$ and $20 \mu \mathrm{L}$. This change in coloration may be instigated by the catabolic genes. Thus the enzymes produced by the genes may be responsible for the blue colored medium. Also the Pseudomonas spp showed highest turbidity (0.7270.371) and lowest $\mathrm{pH}$ values (3.55-3.68). Biodegradation rates are highly variable because they depend on several factors, including the amount and location of chlorination, PCB concentration, type of microbial population, available nutrients, and temperature (Thomas et al., 1992; Robinson and Lenn, 1994). Pseudomonas spp, Arthrobacter spp, and Micrococcus spp utilized the askarel oil ( a PCB blend) appreciably at different concentrations in $15 \mu \mathrm{L}$ and $20 \mu \mathrm{L}$ but minimally at $5 \mu \mathrm{L}$ and $10 \mu \mathrm{L}$. This implies that at higher concentration these organisms degradative enzymes were induced significantly when compared to their behavior at low concentrations of askarel in the minimal medium. Also from bacterial growth kinetics, organisms tend to adapt to the new substrates before actual significant growth occurs and this may provide an explanation to the delay at concentrations in $5 \mu \mathrm{L}$ and $10 \mu \mathrm{L}$. Thus the organisms were slow in acclimatizing to the Askarel oil (PCBs blend) as evidenced with their performance at an increased concentration of $15 \mu \mathrm{L}$ and $20 \mu \mathrm{L}$.

In conclusion, Pseudomonas spp , Arthrobacter spp, Micrococcus spp and Acinetobacter spp are prevalent microorganisms in soils of tropical ecosystem; therefore further research should be carried out on their degradative competence and also possible expansion of their substrate range using biotechnological tools for effective remediation of landfills polluted with waste polychlorinated biphenyls and their derivatives. 


\section{ACKNOWLEDGEMENT:}

Author expresses his deep appreciation to Omonhinmin A.C, Eni O. A, Dike I, and Nwagbara U for their assistance during this research.

\section{REFERENCES}

Adebusoye, S.A., F.W. Picardial, M.O. Ilori, O.O. Amund and C. Fuqua,2008. Characterization of multiple novel aerobic polychlorinated biphenyl (PCB) utilizing bacterial strains indigenous to contaminated tropical frican soils. Biodegradation. 19: 145-159.

Ahmed, M., Focht, D.D (1973).Degradation of polychlorinated biphenyls by two species of Achromobacter. Can J Microbiol 19(1):47-52.

Braune, B.M., Outridge, P.M., Fisk. A.T., Muir. D.C.G, Helm. P.A., Hobbs. K, et al. (2005).Persistent organic pollutants and mercury in marine biota of the Canadian Arctic: An overview of spatial and temporal trends. Sci Total Environ 51(352):4-56.

Bedard, D.L., Haberl M.L May R.J Brennan M.J (1987) Evidence for novel mechanisms of polychlorinated biphenyl metabolism in Alcaligenes eutrophus H850.Appl Environ Microbiol 53:1103-1112

Bopp, L.H., 1986. Degradation of highly chlorinated PCBs by Pseudomonas strain Lb400. Journal of Industrial Microbiology, 1: 23-29.

Buchanan, R.E, N.E. Gibbons, 1974. Bergey's Manual of Determinative Bacteriology 8th edition. The Williams and Wilkins company, Baltimore.

Faroon, O., Keith, L., Smith-Simon, C., De Rosa, C. (2003). Polychlorinated biphenyls. Human health aspects. In: Concise international chemical assessment document 55. World Health Organization, Geneva.

Fava, F., di Gioia, D., Cinti, S., Marchetti . L, Quattroni, G.(1994). Degradation and dechlorination of lowchlorinated biphenyls by a three-membered bacterial co-culture. Appl Microbiol Biotechnol 41:117-23.

Furukawa, K., Tonomura, K., Kamibayashi, A.(1979).Effect of chlorine substitution on the bacterial metabolism of various of polychlorinated biphenyls. Appl Environ Microbiol 38(2):301-310.

Gevao, B., Beg, M.U., Al-Omair, A., Helaleh, Z.J.(2006). Spatial distribution of polychlorinated biphenyls in coastal marine sediments receiving industrial effluents in Kuwait. Arch Environ Contam Toxicol 50:166-74.

Gibson, D.T., Parales, R.E. (2000) Aromatic hydrocarbon dioxygenases in environmental biotechnology. Curr Opin Biotechnol 11:236-243

Imamoglu, M.G., Rayne, S., Addison, R.F.(2002). Exponential increase of brominated flame retardants, polybrominated diphenyl ethers, in the Canadian Arctic from 1981-2000. Environ Sci Technol 36:1886-92.

Kim, I.S., Lee, H., Trevors, J.T. (2001) Effects of 2,2',5,5'tetrachlorobiphenyl and biphenyl on cell membranes of Ralstonia eutropha H850. FEMS Microbiol Lett 200:17-24.

Kim, S and Picardal F.W (2000) A novel bacterium that utilizes monochlorobiphenyls and 4-chlorobenzoate as growth substrates. FEMS Microbiology Letters 185 : 225-229.

Klecka, G., Boethling, B., Franklin, J., Graham, G., Grady, L., Howard, P.H. et al.(2000). Evaluation of persistence and long-range transport of organic chemicals in the environment. FI: SEATAC Special Publication Series ,Pensacola.

Langer, P. (2005). Persistent organochlorinated pollutants (POPs) and human thyroid - . Endocr Regul .39:5368.

Liu ,Z., Yang, H., Huang ,Z., Zhou ,P. and Liu,S.J.(2002).Degradation of aniline by newly isolated,extremely aniline-tolerant Delftia sp.AN3.Appl. Microbiol. Biotechnol.58:679-682.

Mandalakis, M., Stephanou, E.G.(2002). Polychlorinated biphenyls associated with fine particles (PM2.5) in the urban environment of Chile: concentration levels, and sampling volatilization losses. Environ Toxicol Chem 21(11):2270-5.

Nwinyi O.C (2010) .Degradation of Askarel (PCB Blend) by Indigenous Aerobic Bacteria Isolates from Dumpsites in Ore, Ondo State.Nigeria. Australian Journal of Basic and Applied Sciences, 4(8): 3938-3948.

Nwinyi,O.C., Nwodo,C.S., Amund O.O(2008) Biodegradation potential of two Rhodoccocus strain capable of utilizing aniline as Carbon Source in tropical ecosystem. Research Journal of Microbiology.3(2):99104.

Offenberg J, Simcik M, Baker J, Eisenreich S.J (2005) The impact of urban areas on the deposition of air toxics to adjacent surface waters:A mass budget of PCBs in Lake Michigan in 1994. Aquat. Sci. 67: 79-85

Olutiola, PO., O. Famurela, H.E. Sontag, 1991. An introduction to General Microbiology, a practical Approach Heideberger Verlagsanstalt and Druckerei $\mathrm{GmbH}$ Heldelberg Gmbh, Germany.

Prescott ,M.,J.P. Harley and D.A.Klein.(2002).Industrial Microbiology and Biotechnology in General Microbiology.5th edn,Published by McGraw-Hill.

Robinson, G.K., Lenn, M.J. (1994) The bioremediation of polychlorinated biphenyls (PCBs): Problems and perspectives. Biotechnology and Genetic Engineering Reviews, 12:139-188. 
Rogers, J.D.(1999). Sequential anaerobic-anaerobic treatment of polychlorinated biphenyls in soil microcosm. Washington DC: National Center for Environmental Research, USEPA.

Rosenberg E, Rubinotivz C, Gottleb A, Rosenttak S, Ron E.Z (1988) Production of biodispersion by Acinetoabcter calcoaceticus A2 Applied Environmental Microbiology 317-322 vol 54 N0 2.

Rudel R. A, Seryak L M and Brody J. G (2008). PCBcontaining wood floor finish is a likely source of elevated PCBs in residents' blood, household air and dust: a case study of exposure. Environmental Health, $7: 2$

Sawhney, B.L.(1987). Chemistry and properties of PCBs in relation to environmental effects. In Waid JS, editor. PCBs and the Environment. Boca Raton, FL: CRC Press; .pp. 47-64.

Scullion, J (2006) Remediating polluted soils. Naturwissenschaften 93: 51-65.
Sierra, I., Valera, J.L., Marina, M.L., Laborda, F. (2003) Study of the biodegradation process of polychlorinated biphenyls in liquid medium and soil by a new isolated aerobic bacterium (Janibactersp). Chemosphere 53:609-618.

Sikkema, J., Bont, J.A. , Poolman, B. (1995) Mechanisms of membrane toxicity of hydrocarbons. Microbiol Rev 59:201- 222.

Thomas, D.R., Carswell, K.S., Georgiou, G. (1992) Mineralization of biphenyl and PCBs by the white rot fungus Phanerochaete chrysosporium. Biotechnology \& Bioengineering, 40(11):1395-1402.

USEPA(1987).Code of Federal Regulation.40 CFR 707.60.Washington,DC US Environmental Protection Agency.

Wania, F.(2003). Assessing the potential of persistent organic chemicals for long-range transport and accumulation in polar regions. Environ Sci Technol $37: 1344-51$. 